
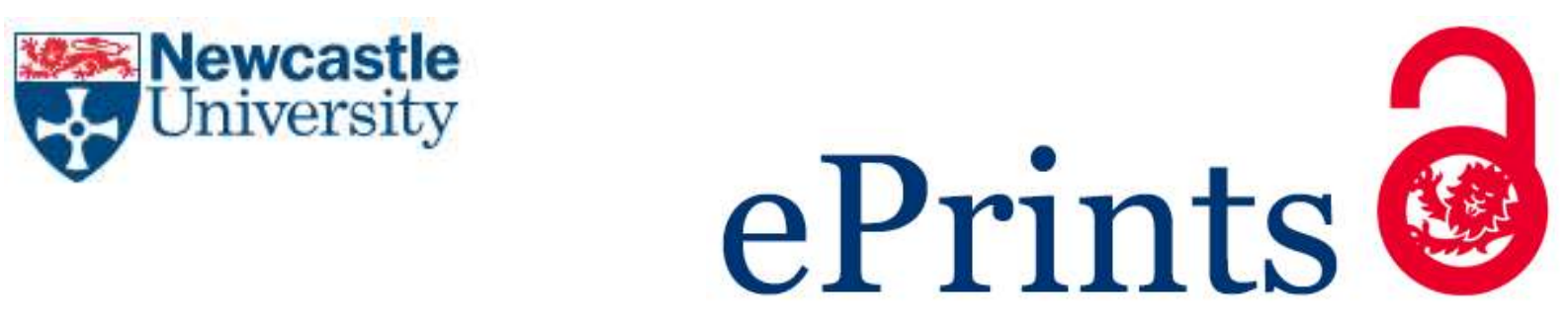

Koh A, Murray H. Probing chromosome dynamics in Bacillus subtilis. In: Methods in Molecular Biology. Springer, 2016, pp.91-108.

\title{
Copyright:
}

The final publication is available at Springer via http://dx.doi.org/10.1007/978-1-4939-3631-1 8

Date deposited:

$07 / 12 / 2017$

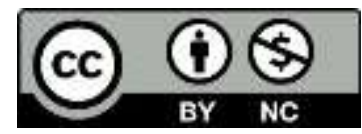

This work is licensed under a Creative Commons Attribution-NonCommercial 3.0 Unported License 


\section{Probing chromosome dynamics in Bacillus subtilis}

\section{Alan Koh and Heath Murray}

\section{Key words}

Microscopy, fluorescent protein, chromosome, DNA replication, DNA segregation, prokaryote

\section{Summary}

Research over the last two decades has revealed that bacterial genomes are, in fact, highly organized. The goal of future research is to understand the molecular mechanisms underlying bacterial chromosome architecture and dynamics during the cell cycle. Here we discuss techniques that can be used with live cells to analyse chromosome structure and segregation in the Gram-positive model organism Bacillus subtilis.

\section{Introduction}

Research into genome organization and dynamics was first established in eukaryotic cells where the condensation and segregation of chromosomes could be readily observed using microscopy techniques. Initial approaches with bacterial cells engendered the belief that chromosomes were compacted but largely unstructured, as they did not display the obvious hallmarks of cell cycle condensation and segregation detected in more complex organisms. However, advances in live cell fluorescence microscopy have revealed that, in fact, bacterial chromosomes are highly organized. Furthermore, recent evidence strongly 
suggests that bacterial genomes are actively segregated and positioned within cells to facilitate accurate genetic inheritance. Bacterial cells, with their relatively small genomes and rapid generation times, provide excellent model systems with which to understand fundamental principles of DNA organization and dynamics.

In most bacteria the critical processes of DNA replication and segregation are coupled during the cell cycle so that following initiation of DNA synthesis the two daughter origin regions are rapidly segregated away from each other [1, 2]. Newly synthesized DNA molecules are thought to be compacted and organized into various domain structures to facilitate segregation $[3,4]$. Although several factors have been identified that are important for bacterial chromosome organization and segregation (e.g. - condensin, ParABS), deletion of such systems often result in either mild or conditional phenotypes, presumably because the overlapping nature of these processes allow the remaining systems to compensate for each other $[1,5,6,7,8]$. Thus, the aims of future studies will be to identify unknown bacterial chromosome organization and segregation factors and to determine how these systems synergize to ensure accurate genome inheritance. In order to achieve these goals researchers will need tools for the characterization of DNA localization and movement within single cells. Below we will describe methods to analyze DNA dynamics in the bacterium Bacillus subtilis, a model organism that is particularly advantageous because its chromosome can be easily manipulated using genetic engineering methods and because it has the ability to differentiate into a dormant spore which requires specific developmental regulation of its chromosome copy number and localization (Figure $1 \mathrm{~A}$ ).

The tool used most frequently to study DNA localization in living cells is the green fluorescent protein (GFP), along with its derivatives that have distinct excitation and emission properties to allow multicolour imaging (cyan $=$ CFP, yellow $=$ YFP, red $=$ RFP). These reporters can be genetically fused to a protein of interest in order to assess its position within the cell. No fixation or permeabilization is required for this approach, thus the signal detected can be observed during live cell growth and development. Although it is 
possible to use fluorescent intercalating dyes to stain DNA in live cells (Figure 2A), we have found there are several drawbacks: (i) the most commonly used stain DAPI is excited using short wavelengths of light which can damage DNA upon prolonged exposure; (ii) alternative stains excited with longer wavelengths are available but more expensive; (iii) most significantly we have observed that staining is often heterogeneous within a population of cells, impeding quantitative analysis.

To easily visualize the entire bacterial nucleoid, FPs can be fused to the highly abundant nucleoid associated histone-like protein (HBsu) (Figure 2A) [9]. Coupling this with lipophilic membrane dyes (e.g. - FM5-95, Nile red) allow bulk chromosome localization and dynamics to be studied in individual cells.

For more specific labelling of the $B$. subtilis chromosome at the DNA replication origin and terminus regions, the endogenous Spo0J/ParB and replication terminator protein (RTP) proteins can be tagged with FPs, respectively. These DNA binding proteins localize to multiple recognition motifs within these regions and generate a punctate fluorescent signal within cells (Figure 3A and 3B) [10, 11, 12]. Furthermore, by measuring the position of the FP tagged origins / terminus or counting the number of origins within each cell; one could quickly determine the location of these tagged regions and the rate of DNA replication initiation respectively (Figure $3 \mathrm{C}-\mathrm{E})$.

In addition to visualizing the replication origin and terminus regions using endogenous proteins, any genetic locus of interest can be investigated by integrating arrays of operator sites that are recognized by fluorescently labelled DNA binding proteins. The two commonly used systems in $B$. subtilis are based on the repressor proteins TetR (binding tetO) and Lacl (binding lacO) (Figure 4) [13, 14]. We wish to highlight the systems constructed by the Sherratt Lab in which the repeated operator sites within the arrays are separated by randomized 10 base pair sequences to reduce recombination and the tetramerization domains of the repressors have been removed to prevent DNA looping [15]. 
Moreover, by fusing DNA binding proteins to different FPs with distinct spectral properties (e.g. - GFP/RFP or CFP/YFP) allowed multiple chromosomal features to be visualized simultaneously (Figure 5) [6, 15].

At this point it is important to note that each of the DNA labelling strategies outlined above have potential shortcomings. First, FP-tags on endogenous proteins will always alter activity to a degree, so although cell growth and chromosome organization/segregation may appear normal in an otherwise wild-type strain background, combining multiple FP-tagged proteins in one strain or combining FP-tagged proteins with other mutants may result in synthetic phenotypes [16]. Second, the repressor/operator arrays have the capacity to block replisome progression [17]. This problem can be mitigated by using arrays containing a small number of binding sites or lowering the expression level of the FP-tagged repressor, although the trade-off is that the fluorescent signal will also be diminished. Since no single labelling technique is without caveats, it is advisable to utilize multiple approaches where possible.

To study chromosome dynamics it can be useful to synchronize DNA replication and segregation events. There are two readily available approaches to synchronize $B$. subtilis cells. First, the DNA replication cycle can be arrested at the initiation stage using temperature sensitive alleles of initiation proteins (e.g. - the helicase loader gene $d n a B 134^{t s}$ ) [18]. After allowing ongoing rounds of DNA synthesis and segregation to be completed, dropping the culture to the permissive temperature produces a synchronous round of chromosome replication and segregation (Figure 6B) [19].

Second, a liquid culture of $B$. subtilis can be resuspended in medium that stimulates the sporulation developmental pathway (Figure 1B). During sporulation cells are arrested as diploids and the two chromosomes adopt an extended conformation (the axial filament) with the chromosome origin region anchored to the cell pole by $\operatorname{RacA}[20,21,22,23]$. Asymmetric cell division will then trap $\sim 25 \%$ of the chromosome into the forespore. As 
sporulation proceeds the remaining chromosome is pumped into the forespore by the translocase SpollIE before the spore is engulfed by the mother cell to complete maturation $[23,24,25]$. Thus, synchronizing sporulation initiation offers the opportunity to study unique aspects of chromosome organization and segregation (Figure 7B).

Here we describe methodologies in live cell imaging to study chromosome dynamics in $B$. subtilis, with a particular focus on the localization and separation of the DNA replication origin.

\section{Materials}

All solutions are prepared using ultrapure water and analytical grade reagents. All solutions and reagents are prepared and stored at room temperature unless specifically stated. All waste disposals were carried out using approved disposal procedures. All components are sterilized either by autoclaving at 15 psi for 30 min or for heat labile solutions by filtering $(0.45 \mu \mathrm{m})$.

\subsection{Origin separation, counting and positioning assay}

1. Overnight culture Spizizen minimal medium (SMM) based media: $0.2 \%$ $\mathrm{NH}_{4} \mathrm{SO}_{4}, 1.4 \% \mathrm{~K}_{2} \mathrm{PO}_{4}, 0.6 \% \mathrm{KH}_{2} \mathrm{PO}_{4}, 0.1 \%$ sodium citrate dehydrate, $0.02 \%$ $\mathrm{MgSO}_{4}, 0.01 \mathrm{mg} / \mathrm{ml} \mathrm{Fe} \mathrm{NH}_{4}$-citrate, $6 \mathrm{mM} \mathrm{MgSO}_{4}, 0.1 \mathrm{mM} \mathrm{CaCl}, 0.13 \mathrm{mM}$ $\mathrm{MnSO}_{4}, 1 \mu \mathrm{M} \mathrm{ZnCl}_{2}, 2 \mu \mathrm{M}$ thiamine, $0.1 \%$ glutamate, $0.02 \mathrm{mg} / \mathrm{ml}$ tryptophan, $200 \mu \mathrm{g} / \mathrm{ml}$ casein hydrolysate, $2.0 \%$ succinate and inducers as needed (1 $\mu \mathrm{g} / \mathrm{ml}$ tetracycline, $500 \mathrm{ng} / \mathrm{ml}$ anhydrotetracycline or $1 \mathrm{mM}$ IPTG).

2. SMM based media supplemented with the following carbon source: $2 \%$ succinate for slow growth, $2 \%$ glucose for medium growth or $2 \%$ glucose + 
$200 \mu \mathrm{g} / \mathrm{ml}$ casein hydrolysate for fast growth. Note that no inducer should be added into the fresh media.

3. Test-tubes or $125 \mathrm{ml}$ conical flasks.

4. Shaking incubator with temperature setting.

\subsection{Sporulation assay}

1. Casein hydrosylate media (CHM): $1 \%$ casein hydrosylate, $0.46 \%$ L-glutamic acid sodium salt, $0.13 \% \mathrm{~L}$-alanine, $0.14 \% \mathrm{~L}$-asparagine, $0.14 \% \mathrm{KH}_{2} \mathrm{PO}_{4}$, $0.05 \% \mathrm{NH}_{4} \mathrm{Cl}, 0.01 \% \mathrm{Na}_{2} \mathrm{SO}_{4}, 0.01 \% \mathrm{NH}_{4} \mathrm{NO}_{3}, 0.98 \mathrm{mg} \mathrm{FeCl}{ }_{3} .6 \mathrm{H}_{2} \mathrm{O}$ and adjusted to $\mathrm{pH} 7.0$ with $\mathrm{NaOH}$ or $\mathrm{HCl}$. After that add $0.1 \mathrm{mM} \mathrm{CaCl}_{2}, 0.4 \mathrm{mM}$ $\mathrm{MgSO}_{4}, 0.13 \mathrm{mM} \mathrm{MnSO}_{4}, 0.02 \mathrm{mg} / \mathrm{ml}$ tryptophan and inducers as needed (1 $\mu \mathrm{g} / \mathrm{ml}$ tetracycline, $500 \mathrm{ng} / \mathrm{ml}$ anhydrotetracycline or $1 \mathrm{mM}$ IPTG).

2. Sporulation salts solution (Solution A): $4 \mathrm{mM} \mathrm{FeCl}_{3}, 40 \mathrm{mM} \mathrm{MgSO}_{4}$ and 100 $\mathrm{mM} \mathrm{MgCl}$.

3. Sporulation salts solution (Solution $\mathrm{B}$ ): $1 \mathrm{M} \mathrm{NH}_{4} \mathrm{Cl}, 75 \mathrm{mM} \mathrm{Na}_{2} \mathrm{SO}_{4}, 50 \mathrm{mM}$ $\mathrm{KH}_{2} \mathrm{PO}_{4}$ and $120 \mathrm{mM} \mathrm{NH}_{4} \mathrm{NO}_{3}$ adjusted to $\mathrm{pH} 7.0$ with $\mathrm{HCl}$ or $\mathrm{NaOH}$. Sterile filter both solutions and store at $4^{\circ} \mathrm{C}$.

4. Sporulation salts solution (Solution $A+B$ ): $M i x 1 \mathrm{ml}$ of solution $A$ with $10 \mathrm{ml}$ of solution B and top up with water to make $1 \mathrm{~L}$. Autoclave the sporulation salts solution.

5. Sporulation media $(S M)$ : Sporulation salts (solution $A+B$ ) supplemented with $0.2 \%$ glutamate, $1 \mathrm{mM} \mathrm{CaCl}_{2}, 40 \mathrm{mM} \mathrm{MgSO}_{4}$ and $0.02 \mathrm{mg} / \mathrm{ml}$ tryptophan.

6. Test-tubes or $125 \mathrm{ml}$ conical flasks.

7. Shaking incubator with temperature setting. 


\subsection{General microscopy}

1. Prepare $\sim 1.5 \%$ agarose gel in the media that was used for the cell culture. (See Note 1 and 2)

2. Prepare $200 \mu \mathrm{g} / \mathrm{ml}$ of stock FM5-95 membrane dye and mix it with the molten agarose to a final concentration of $0.5 \mu \mathrm{g} / \mathrm{ml}$. (See Note 3)

3. If desired prepare $10 \mu \mathrm{g} / \mathrm{ml}$ of stock DAPI stain and mix it with cells to stain the DNA to a final concentration of $0.6 \mu \mathrm{g} / \mathrm{ml}$.

4. Multi-spot microscope slide (Figure 8A) or a Gene Frame (Life Technologies, cat no: AB-0578; $17 \mathrm{~mm}$ x $28 \mathrm{~mm}$ ) mounted on a clear microscope slide (Figure 8B).

5. Glass coverslip

6. Surgical scalpel blades

7. Prepare $70 \%$ ethanol

8. Epifluorescence microscope with appropriate filter sets.

9. METAMORPH software (version V.6.2r6) for image capture.

10. ImageJ software $(1.49 n)$ can be downloaded at the following URL http://imagej.nih.gov/ij/

11. ImageJ plugin for cell counter can be downloaded at the following URL http://imagej.nih.gov/ij/plugins/cell-counter.html

12. ImageJ plugin for ObjectJ can be downloaded at the following URL https://sils.fnwi.uva.nl/bcb/objectj/ 


\section{Methods}

\subsection{Growth conditions for origin separation, counting and positioning assay}

1. To visualize cells during exponential growth, $2 \mathrm{ml}$ of starter cultures were grown overnight at either $30^{\circ} \mathrm{C}$ or $37^{\circ} \mathrm{C}$ in SMM based media. (See Note 4 to 8)

2. The next day, $1 \mathrm{ml}$ cultures were washed twice with fresh SMM based media to remove any remaining inducer molecules (this step can be skipped if no inducer was used for the overnight culture).

3. Dilute culture 1:100 into fresh SMM based media supplemented with $2.0 \%$ succinate, $2.0 \%$ glucose, or $2.0 \%$ glucose $+200 \mu \mathrm{g} / \mathrm{ml}$ casein hydrolysate. (See Note 9 to 11 )

4. Allow cultures to achieve at least three mass doublings $\left(A_{600} 0.3-0.5\right)$ before observation by microscopy. (See Method 3.4 and 3.5)

\subsection{Synchronization of DNA replication}

1. To visualize a synchronized DNA replication and segregation cycle, $5 \mathrm{ml}$ of starter culture was grown overnight at the permissible temperature of $30^{\circ} \mathrm{C}$ in CHM with inducer as needed. (See Note 4 to 8) (Figure 6A; flow chart)

2. The next day, $1 \mathrm{ml}$ cultures were washed twice with fresh $\mathrm{CHM}$ to remove any remaining inducer molecule (this step can be skipped if no inducer was used for the overnight) before being diluted 1:100 into fresh $\mathrm{CHM}$.

3. At an $\mathrm{A}_{600}$ of $0.1,5 \mathrm{ml}$ of fresh $\mathrm{CHM}$ that have been prewarmed to $70^{\circ} \mathrm{C}$ was added into the culture. This will rapidly equilibrate the culture temperature to the non-permissive temperature $\left(\sim 50^{\circ} \mathrm{C}\right)$ and allowed further growth at this temperature for 90 min to allow ongoing rounds of replication to complete. 
4. To initiate DNA replication, the culture was shifted back to the permissible temperature $\left(30^{\circ} \mathrm{C}\right)$.

5. Observe DNA replication by microscopy. (See Method 3.4 and 3.5)

\subsection{Sporulation assay}

1. To visualize cells during sporulation, $2 \mathrm{ml}$ of starter cultures were grown overnight at $30^{\circ} \mathrm{C}$ in $\mathrm{CHM}$ media. (See Note 4 and 8) (Figure 7A; flow chart)

2. The next day the overnight cultures were diluted into $2 \mathrm{ml}$ of fresh $\mathrm{CHM}$ media to achieve a starting $A_{600}$ of 0.1 , and then incubated at $37^{\circ} \mathrm{C}$ until they reached an $A_{600}$ of 1.0 .

3. The cultures were then centrifuged at $16000 \times \mathrm{g}$ for $10 \mathrm{~min}$ and the cell pellet was resuspended in $2 \mathrm{ml}$ of fresh SM.

4. Transfer $2 \mathrm{ml}$ of the resuspended culture back into the same test tube to induce sporulation according to the resuspension method of [26] and modified by [27] for at least 120 min before observation by microscopy. (See Method

\section{4 and 3.5$)$}

\subsection{Preparation of multi-spot microscope slide}

1. Clean the multi-spot microscope slide with $70 \%$ ethanol and ensure that it is dry and free of dust.

1. Pipette $750 \mu \mathrm{l}$ of molten agarose onto the middle of the slide. Ensure that there is no air bubble in the agarose as this might interfere with how the agarose pad will harden. (See Note 12)

2. Quickly place a standard microscope slide on top of the molten agarose and squeeze any excess agarose out by gently pressing down on the slide. (See Note 13) 
3. Air dry to allow the media to absorb into the pad. This normally takes about 5 min. (See Note 14)

4. Carefully remove the standard microscope slide on top of the multi-spot microscope slide to reveal the agarose.

5. Pipette $\sim 1 \mu \mathrm{l}$ of cell culture onto the agarose pad. (See Note 15)

6. Air dry to allow the media to absorb into the pad. This normally takes about 5 min. (See Note 14)

7. Place a clean coverslip on top of the cells. (See Note 16)

8. The microscope sample is now ready for imaging (Table 1).

\subsection{Preparation of microscope slide (Gene frame)}

1. Clean the microscope slide with $70 \%$ ethanol and ensure that it is dry and free of dust.

2. Carefully remove the plastic cover from the gene frame (i.e. - the side with the solid plastic covering the whole gene frame) which will reveal the sticky pad.

3. Attach the gene frame with the sticky pad onto the middle of a standard microscope slide. Use the edge of a pen and move along the frame ensuring that there are no air bubbles between the frame and the slide (note that the upper side of the sticky gene frame will remain covered with a plastic mask).

4. Pipette $500 \mu \mathrm{l}$ of molten agarose onto the middle of the gene frame. Ensure that the agarose exceeds the volume of the gene frame and that there are no air bubbles in the agarose. (See Note 12)

5. Quickly place a standard microscope slide on top of the molten agarose. Squeeze excess agarose out by gently pressing down on the slide. (See Note 13)

6. To harden the agarose, place the gene frame horizontally into a petri dish that contains a small ball of wet tissue (to prevent desiccation). Cover the 
petri dish and store it in the refrigerator at $4^{\circ} \mathrm{C}$ for at least $30 \mathrm{~min}$. (See Note 14)

7. To prepare the slides for microscopy, warm the microscope slides by shifting the petri dishes into the desired temperature (depending on experimental requirements) for at least $30 \mathrm{~min}$. (See Note 12)

8. Carefully remove the clear microscope slide on top of the gene frame to reveal the agarose. (See Note 14)

9. To provide a source of oxygen create air pockets using a scalpel to cut out agar strips (Figure 8B).

10. Pipette $\sim 1 \mu \mathrm{l}$ of cell culture onto the agarose pad. (See Note 15)

11. Air dry to allow the media to absorb into the pad. This normally takes about 5 $\min$. (See Note 14)

12. Remove the mask from the gene frame and firmly attach a clean cover slip, ensuring no gaps are present. (See Note 16)

13. The microscope sample is now ready for imaging (Table 1).

14. For time lapse microscopy incubate the prepared microscope slide at the desired temperature for at least $30 \mathrm{~min}$.

15. The microscopy chambers should also be prewarmed to the desired temperature for at least $1 \mathrm{hr}$ before commencing the time lapse experiment.

\subsection{Measurement of focus position within cells with two foci (replication origin and terminus positioning)}

1. Cells are grown as described in (Method 3.1).

2. ImageJ software with ObjectJ plugin was utilized for determining the focus position within the cell (Figure 3C). 
3. For each cell, the focus closest to an arbitrarily selected pole was designated "near", and the other focus was designated "far". Three measurements were made: (i) the distance from the pole to the center of the proximal focus (near); (ii) the distance from the same pole to the center of the distal focus (far); and (iii) the distance between the two poles (cell length).

4. To determine the position of the near focus within the cell, the measured distance was divided by the cell length and multiplied by 100 to give the focus position as a percentage of cell length. To determine the position of the far within the cell, the measured distance was subtracted from the cell length before being divided by the cell length, then being multiplied by 100 to give the focus position as a percentage of cell length. These numbers were averaged for all cells in a sample. The $95 \%$ confidence intervals for the mean were calculated.

5. Interfocal distance was calculated by subtracting the position of the near focus from the far focus, then dividing by cell length and multiplying by 100 to give the interfocal distance as a percentage of cell length. These numbers were averaged for all cells in a sample. The 95\% confidence intervals for the mean were calculated.

\subsection{Counting the number of different class of cells (Origin separation) and the number of origin per cell (Origin counting)}

1. Cells are growth as described in (Method 3.1).

2. ImageJ software with cell counter plugin was utilized to determine the number of different type of cells or the number of origins per cell. 


\section{Notes}

1. Minimise the use of complex media such as PAB, LB and $\mathrm{CH}$, which produce high autofluorescence. While minimal media has a lower autofluorescence level.

2. Always prepare fresh agarose solution on the day of the experiment and ensure that the agarose is complete dissolved to prevent agarose crystallization and store the solution at $\sim 60{ }^{\circ} \mathrm{C}$ to prevent it from solidifying.

3. Mix the membrane dye with the agarose solution $\sim 1 \mathrm{hr}$ before the anticipated microscopy session; in our hands this produces the most uniform straining. Note that exposing the dye to light and high temperature will reduce its efficacy over time.

4. B. subtilis requires thorough aeration for optimum growth and development; therefore ensure vigorous shaking of the culture. Normally a $>1: 20$ ratio (culture volume:container volume) is desired.

5. Maintain and grow overnight culture of strains that harbour the large $\sim 150$ tetO array with $1 \mathrm{\mu g} / \mathrm{ml}$ tetracycline (only if the strain is resistance to tetracycline) or $500 \mathrm{ng} / \mathrm{ml}$ anhydrotetracycline and large 150 lacO array with $1 \mathrm{mM}$ IPTG to inhibit TetR and Lacl binding to its operator sites, respectively.

6. Use fresh colonies streaked onto nutrient agar plates for each experiment.

7. Allow strains that exhibit slower growth rates a longer overnight incubation period to allow the overnight culture to achieve a high density.

8. Prewarm media before use to prevent temperature shock to the bacteria.

9. Care should be taken to prevent $B$. subtilis from entering the sporulation developmental pathway as this could interfere with the positioning of the chromosome and thus the origin.

10. There is a positive correlation between DNA replication initiation and nutrientmediated growth rates. Therefore in complex media such as PAB, LB and 
$\mathrm{CH}$, cells undergo faster growth rate as compared to minimal media supplemented with the various type of carbon sources.

11. Media such as minimal media which support slower growth rate will result in cells having fewer origins/chromosomes per cell, therefore making analysis less complicated.

12. Reduce exposing the sample and the microscope slide to rapid temperature changes. Try to do all steps in the desired experimental temperature.

13. Ensure that the agarose pad is evenly spread onto the microscope slide to achieve best imagining for the field of cells. To achieve this, it is recommended that the gene frame be used.

14. Avoid exposing the agarose pad to the external environment for too long as this will cause excessive drying.

15. Agitate the culture before removing samples for imaging to reduce cells from clumping together.

16. To prevent air bubbles from accumulating under the coverslip, use the edge of the pen and moves it firmly from one end of the cover slip to the other. This will force any air pockets between the cover slip and agarose pad out.

\section{Acknowledgement}

This work was supported by a grant from the BBSRC (BB/K017527/1) and a Royal Society University Research Fellowship to HM. 


\section{References}

1. Wang XD, Llopis PM, Rudner DZ (2014) Bacillus subtilis chromosome organization oscillates between two distinct patterns. P Natl Acad Sci USA 111:12877-12882

2. Viollier PH, Thanbichler M, Mcgrath PT et al (2004) Rapid and sequential movement of individual chromosomal loci to specific subcellular locations during bacterial DNA replication. P Natl Acad Sci U S A 101:9257-9262

3. Mercier R, Petit MA, Schbath S et al (2008) The MatP/matS Site-Specific System Organizes the Terminus Region of the E. coli Chromosome into a Macrodomain. Cell $135: 475-485$

4. Valens M, Penaud S, Rossignol M et al (2004) Macrodomain organization of the Escherichia coli chromosome. Embo J 23:4330-4341

5. Ireton K, Gunther NW, Grossman AD (1994) Spo0j Is Required for Normal Chromosome Segregation as Well as the Initiation of Sporulation in Bacillus subtilis. J Bacteriol 176:5320-5329

6. Lee PS, Grossman AD (2006) The chromosome partitioning proteins Soj (ParA) and Spo0J (ParB) contribute to accurate chromosome partitioning, separation of replicated sister origins, and regulation of replication initiation in Bacillus subtilis. Mol Microbiol 60:853-869

7. Gruber S, Veening JW, Bach J et al (2014) Interlinked sister chromosomes arise in the absence of condensin during fast replication in B. subtilis. Curr Biol 24:293-298

8. Britton RA, Lin DC, Grossman AD (1998) Characterization of a prokaryotic SMC protein involved in chromosome partitioning. Gene Dev 12:1254-1259

9. Kohler P, Marahiel MA (1997) Association of the histone-like protein HBsu with the nucleoid of Bacillus subtilis. J Bacteriol 179:2060-2064

10. Lee PS, Lin DCH, Moriya S et al (2003) Effects of the chromosome partitioning protein Spo0J (ParB) on oriC of positioning and replication initiation Bacillus subtilis. J Bacteriol 185:1326-1337 
11. Teleman AA, Graumann PL, Lin DCH et al (1998) Chromosome arrangement within a bacterium. Curr Biol 8:1102-1109

12. Lin DC, Levin PA, Grossman AD (1997) Bipolar localization of a chromosome partition protein in Bacillus subtilis. P Natl Acad Sci U S A 94:4721-4726

13. Dworkin J, Losick R (2002) Does RNA polymerase help drive chromosome segregation in bacteria? P Natl Acad Sci USA 99:14089-14094

14. Gordon GS, Sitnikov D, Webb CD et al (1997) Chromosome and low copy plasmid segregation in E. coli: visual evidence for distinct mechanisms. Cell 90:1113-1121

15. Lau IF, Filipe SR, Soballe B et al (2003) Spatial and temporal organization of replicating Escherichia coli chromosomes. Mol Microbiol 49:731-743

16. Gruber S, Errington J (2009) Recruitment of Condensin to Replication Origin Regions by ParB/Spo0J Promotes Chromosome Segregation in B. subtilis. Cell 137:685-696

17. Possoz C, Filipe SR, Grainge I et al (2006) Tracking of controlled Escherichia coli replication fork stalling and restart at repressor-bound DNA in vivo. Embo J 25:25962604

18. Mendelson NH, Gross JD (1967) Characterization of a temperature-sensitive mutant of Bacillus subtilis defective in deoxyribonucleic acid replication. J Bacteriol 94:16031608

19. Su'etsugu M, Errington J (2011) The Replicase Sliding Clamp Dynamically Accumulates behind Progressing Replication Forks in Bacillus subtilis Cells. Mol Cell $41: 720-732$

20. Ben-Yehuda S, Fujita M, Liu XS et al (2005) Defining a centromere-like element in Bacillus subtilis by Identifying the binding sites for the chromosome-anchoring protein RacA. Mol Cell 17:773-782

21. Ben-Yehuda S, Rudner DZ, Losick R (2003) RacA, a bacterial protein that anchors chromosomes to the cell poles. Science 299:532-536

22. Wu LJ, Errington J (2003) RacA and the Soj-Spo0J system combine to effect polar chromosome segregation in sporulating Bacillus subtilis. Mol Microbiol 49:1463-1475 
23. Wu LJ, Errington J (1994) Bacillus subtilis SpollIE Protein Required for DNA Segregation during Asymmetric Cell-Division. Science 264:572-575

24. Bath J, Wu LJ, Errington J et al (2000) Role of Bacillus subtilis SpollIE in DNA transport across the mother cell-prespore division septum. Science 290:995-997

25. Wu LJ, Errington J (1997) Septal localization of the SpollIE chromosome partitioning protein in Bacillus subtilis. Embo J 16:2161-2169

26. Sterlini JM, Mandelstam J (1969) Commitment to sporulation in Bacillus subtilis and its relationship to development of actinomycin resistance. Biochem J 113:29-37

27. Partridge SR, Errington J (1993) The importance of morphological events and intercellular interactions in the regulation of prespore-specific gene expression during sporulation in Bacillus subtilis. Mol Microbiol 8:945-955 


\section{Figure 1: Bacillus subtilis developmental pathways}

Cartoon representation showing the different growth patterns of Bacillus subtilis. (A) Under favourable conditions, $B$. subtilis undergoes vegetative growth and divides by binary fission (Green dotted box). (B) During conditions of nutrient deprivation and high cell density, $B$. subtilis undergoes a differentiation process that involves the formation of a stress resistant spore. (i and ii) Sporulation requires a diploid state where the chromosomes form an axial filament and the replication origin regions (green circle) are anchored to the cell poles by RacA and DivIVA. Formation of the asymmetric septum (orange dotted ring) near one pole leads to the capture of $\sim 25 \%$ of the chromosome surrounding oriC in the forespore. The remaining $\sim 75 \%$ of the chromosome in the mother cell is then pumped into the forespore by the translocase, SpollIE. (iii) As sporulation proceeds, the forespore is engulfed by the mother cell. (iv) Following spore maturation the mother cell will lyse, releasing the spore into the environment. (v) Spores remain dormant until conditions favourable for growth are encountered, whereupon they will germinate and resume vegetative growth.

\section{Figure 2: Bulk chromosome localization within the cell.}

Strains were grown at either $30^{\circ} \mathrm{C}$ or $37^{\circ} \mathrm{C}$ until mid-exponential phase. Cell membranes were stained with FM5-95 dye to distinguish individual cells. (A) Bulk chromosome morphology was visualized with (i) the nucleoid associated DNA binding protein HBsu-GFP or (ii) the DNA stain DAPI. (B) The origin region and the nucleoid were visualized simultaneously using TetR-YFP binding to a tetO array ( 150 operator sites) inserted near the replication origin $\left(359^{\circ}\right)$ and the nucleoid visualized with HBsu-RFP. 
Figure 3: Visualization of the replication origin and terminus with fluorescently labelled proteins.

Strains were grown at $37^{\circ} \mathrm{C}$ until exponential phase. Cell membranes were stained with FM5-95 dye to distinguish individual cells. (A) The origin can be visualized using Spo0J-GFP binding to origin proximal parS sites (grey dots). The spo0J-gfp fusion was expressed from its native locus at $359^{\circ}$. (B)The terminus can be visualized using RTP-GFP binding to nine ter sites located at the terminus region (green dots). The rtp-gfp fusion was expressed from its native locus located at $178^{\circ}$. (C) The origin/terminus localization assay was used to determine the position of each chromosome region within the long axis of the cell. The origin position was determined by visualizing the oriC region using either Spo0J-GFP binding to origin proximal parS sites or TetR-GFP binding to a tetO array near the replication origin. Schematic diagrams illustrate the measurements for either the (i) origin or (ii) terminus position in cells with two foci. For a detailed explanation of the measurement, please see method 3.6. (D) Quantification of origin and terminus localization within the cell. Approximately 100 cells were measured for each reporter strain. The $95 \%$ confidence intervals for the mean were calculated. (E) The origin counting assay was used to determine the average rate of DNA replication initiation. Reporter strains using Spo0J-GFP binding to origin proximal parS sites were grown at $37^{\circ}$. Cell membranes were stained with FM5-95 dye to distinguish individual cells. Qualification of Spo0J-GFP foci per cell in the wild-type strain (green bar) and a mutant that overinitiates DNA replication (red bar) reveals the mutant phenotype (for each strain approximately 500 cells were analyzed). For a detailed explanation of the measurement, please see method 3.7. 
Figure 4: Construction of the TetR/tetO and Lacl/lacO reporter system in B. subtilis.

Cartoon representation showing the construction of the reporter systems. (i) Organization of the lacO/tetO operator sequence (up to 240 operator repeats) arranged into arrays that contains 10 basepairs of randomized nucleotide sequence between each operator sequence. (ii) Plasmids containing either the tetO array or tetR-gfp are stably integrated into the chromosome by double-crossover. (iii) Successful construction allows visualization of the tetO-proximal locus bound by TetR-GFP using epifluorescence microscopy.

\section{Figure 5: The origin separation assay.}

Strains were grown at $30^{\circ} \mathrm{C}$ in minimal growth media to avoid overlapping rounds of DNA replication. (i) Schematic diagram showing the location of the tetO array ( 150) inserted near the replication origin $\left(359^{\circ}\right)$ (visualized using TetR-YFP; green dot) and the location of the lacO array $(\sim 150)$ inserted $\sim 150 \mathrm{~kb}$ down the left chromosome arm at $345^{\circ}$ (visualized using Lacl-CFP; red dot). (ii) A newborn cell that recently underwent cell division. (iii) A cell has initiated DNA replication and segregated the duplicated origin regions. (iv) DNA replication and segregation proceeds normally. (v) Successful formation of two identical daughter cells. (vi) A cell displaying a defect in separation of sister origins. 


\section{Figure 6: Synchronization of DNA replication using a dnaB134ts mutant and}

localization of the replication origin using Spo0J-GFP.

(A) Experimental overview showing the major steps involved in synchronizing DNA replication in a dnaB134ts mutant. For a detailed explanation of the procedure, see method 3.2. (B) The origin region was visualized using Spo0J-GFP binding to origin proximal parS sites in a $d n a B 134^{\text {ts }}$ mutant after synchronizing DNA replication. Cells were imaged every 15 min after shifting to the permissible temperature $\left(30^{\circ} \mathrm{C}\right)$, displaying a synchronous increase in Spo0J-GFP foci per cell as replication proceeds. A white line (-) denotes boundary between cells.

Figure 7: The replication origin trapping assay during sporulation using the TetR/tetO reporter system.

(A) Experimental overview showing the major steps involved in the sporulation assay. For a detailed explanation of the procedure, see method 3.3. (B) The origin region was localized by visualizing TetR-GFP binding to a tetO array ( 25) inserted near the replication origin $\left(353^{\circ}\right)$. TetR-GFP localization was determined during sporulation of B.subtilis cells $120 \mathrm{~min}$ post resuspension in sporulation medium. Cell membranes were stained with FM5-95 dye to identify individual cells undergoing spore development. Enlarged images highlight cells displaying either (i) normal origin localization or (ii) origin trapping defects (denoted with an asterisk *). 
Figure 8: Layout of a multi-spot microscope slide and a gene frame on a microscope slide

(A) Image showing a multi-spot microscope slide. (B) Schematic diagrams showing the layout of a gene frame microscope slide for either (i) two or (ii) four different strains. Note that the agarose pads have been stained with brilliant blue dye to allow their visualization in the images shown.

Table 1: Suggested growth conditions and exposure times for fluorescent reporters

Table showing the suggested growth conditions and exposure times for each fluorescent reporter used in this paper. 


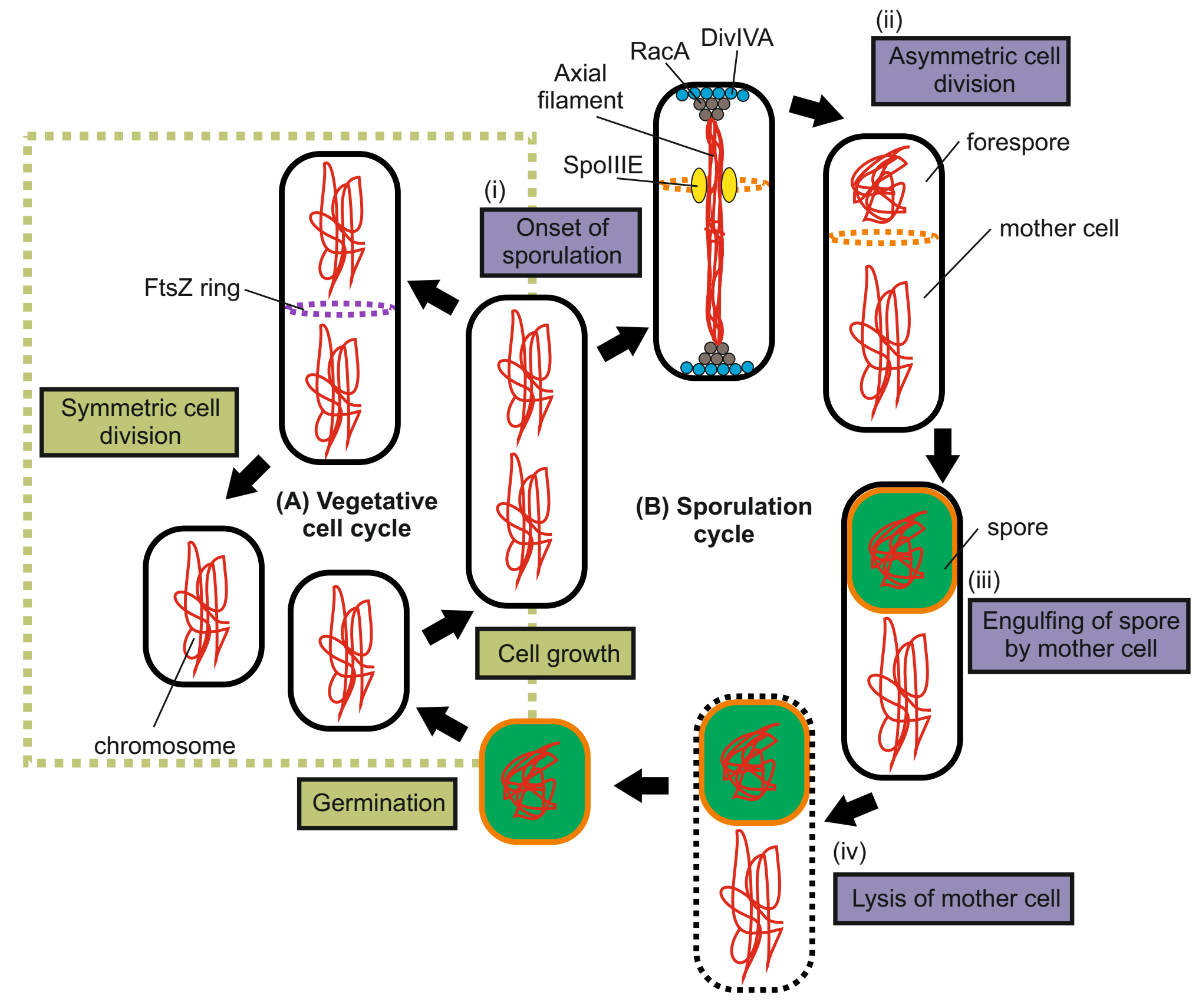

Figure 1 
(A)
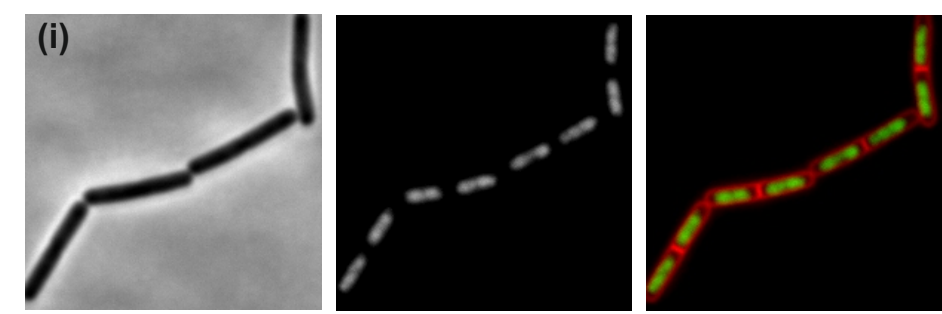

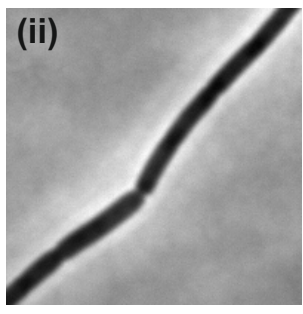

phase contrast

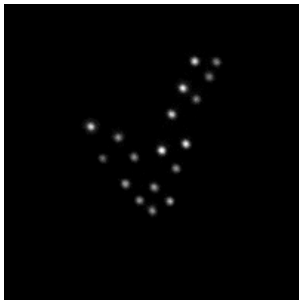

TetR-YFP

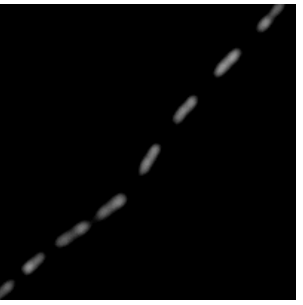

HBsu-GFP / DAPI

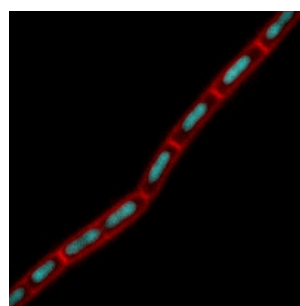

HBsu-GFP /

DAPI +

membrane dye

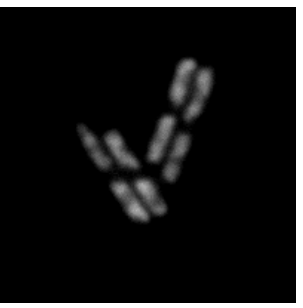

HBsu-RFP

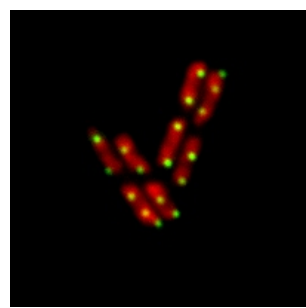

TetR-YFP + HBsu-RFP

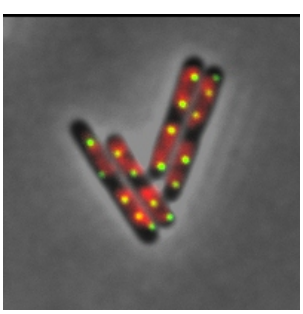

TetR-YFP + HBsu-RFP + brightfield

(C)

\begin{tabular}{|c|c|c|c|c|}
\hline Fluorophore/Stain & Array size & $\begin{array}{l}\text { Average } \\
\text { exposure time }\end{array}$ & $\begin{array}{l}\text { Optimum growth } \\
\text { temperature }\end{array}$ & $\begin{array}{l}\text { Repressor/Stain } \\
\text { Concentration }\end{array}$ \\
\hline TetR-GFP & $\sim 25$ tetO & $3-5 s$ & $30^{\circ} \mathrm{C}-37^{\circ} \mathrm{C}$ & Tetracycline $(1 \mu \mathrm{g} / \mathrm{ml})$ or \\
\hline TetR-YFP & $\sim 150$ tetO & $5 \mathrm{~s}$ & $30^{\circ} \mathrm{C}$ & Anhydrotetracycline $(500 \mathrm{ng} / \mathrm{ml})$ \\
\hline Lacl-CFP & $\sim 150$ lacO & $5 \mathrm{~s}$ & $30^{\circ} \mathrm{C}-37^{\circ} \mathrm{C}$ & IPTG $(1 \mathrm{mM})$ \\
\hline Spo0J-GFP & parS sites & $3-5 s$ & $30^{\circ} \mathrm{C}-37^{\circ} \mathrm{C}$ & nil \\
\hline RTP-GFP & ter sites & $5 \mathrm{~s}$ & $30^{\circ} \mathrm{C}-37^{\circ} \mathrm{C}$ & nil \\
\hline DAPI & chromosome & $3-5 s$ & $30^{\circ} \mathrm{C}-37^{\circ} \mathrm{C}$ & DAPI $(0.2 \mu \mathrm{g} / \mathrm{ml})$ \\
\hline HBsu-GFP & chromosome & $3-5 s$ & $30^{\circ} \mathrm{C}-37^{\circ} \mathrm{C}$ & nil \\
\hline HBsu-RFP & chromosome & $3-5 s$ & $30^{\circ} \mathrm{C}-37^{\circ} \mathrm{C}$ & nil \\
\hline FM5-95 & cell membrane & $3 \mathrm{~s}$ & nil & $\begin{array}{c}\text { Add FM5-95 }(0.4 \mu \mathrm{g} / \mathrm{ml}) \\
\text { to agarose }\end{array}$ \\
\hline brightfield & whole cell & $100 \mathrm{~ms}$ & nil & nil \\
\hline
\end{tabular}

\section{Figure 2}



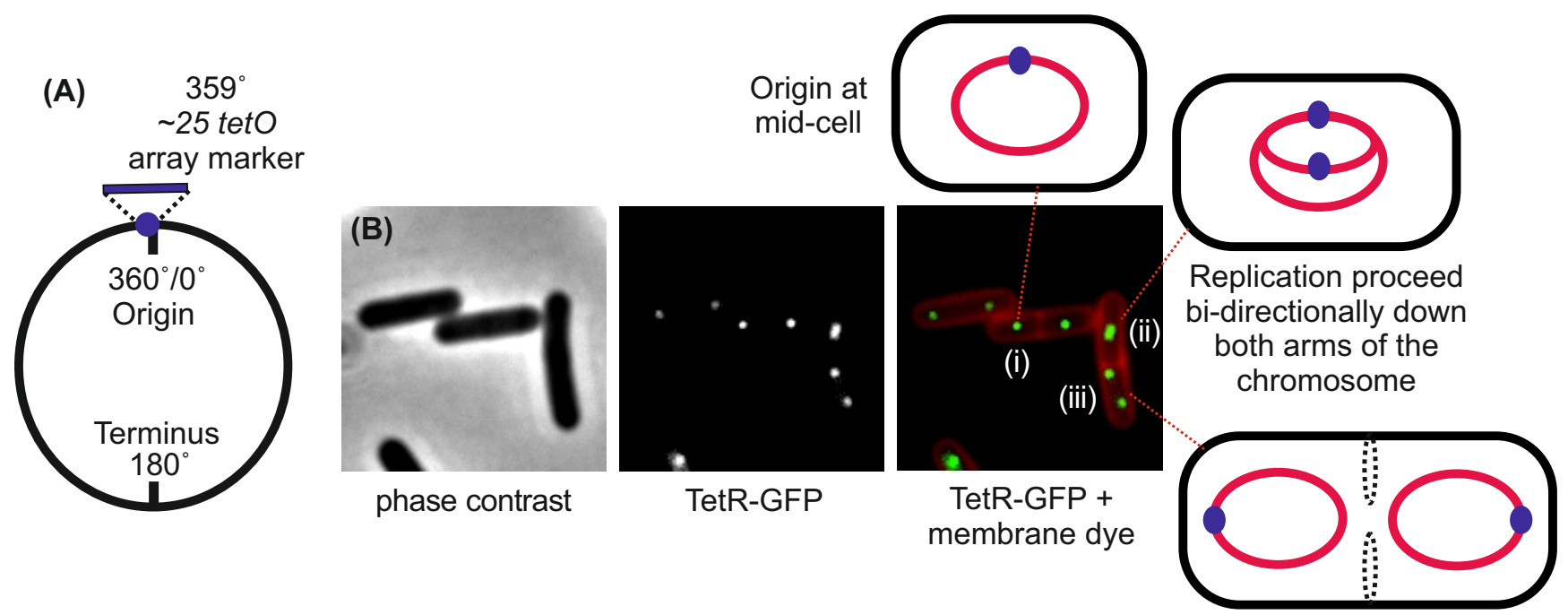

(C)

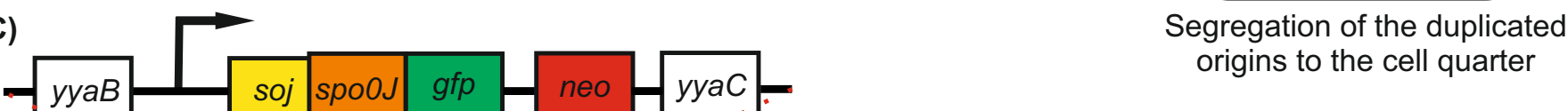

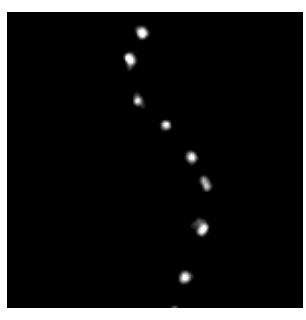

GFP-Spo0J

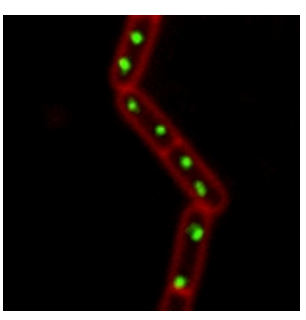

GFP-Spo0J + membrane dye

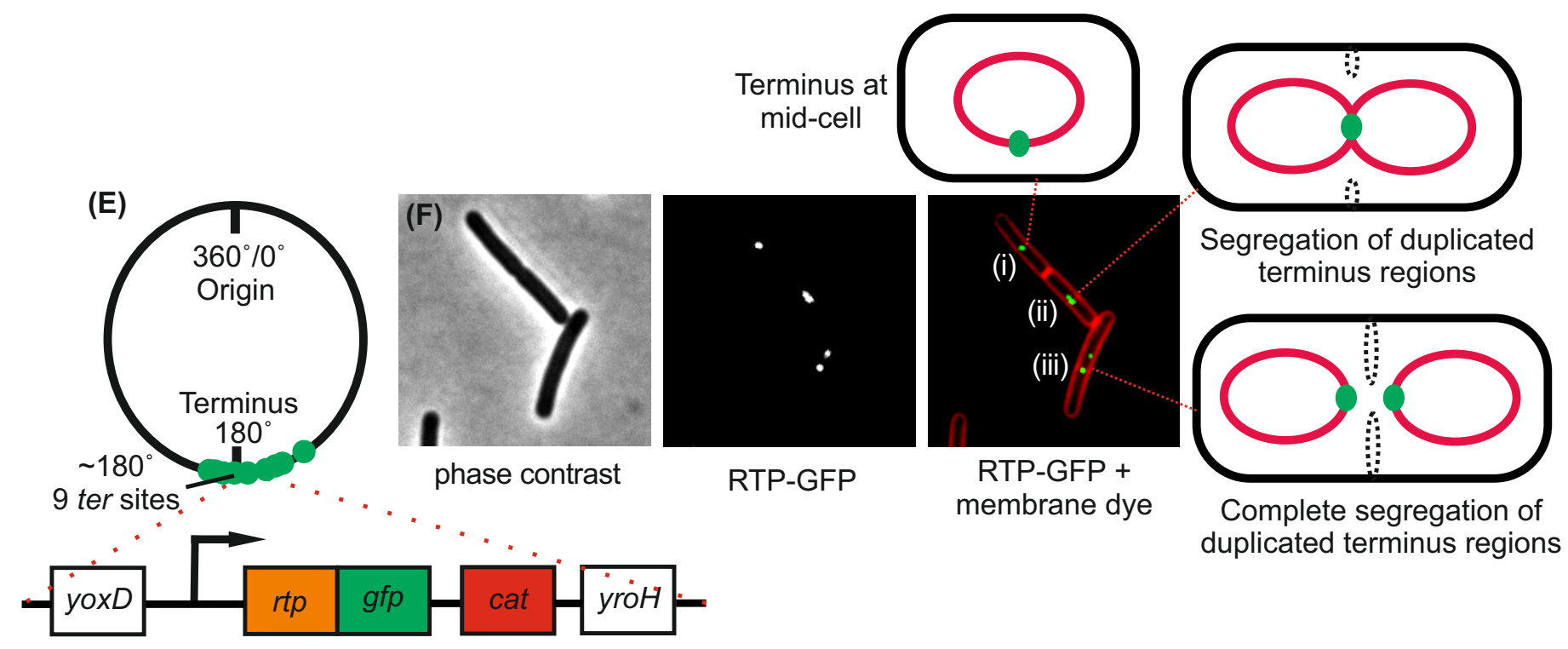

\section{Figure 3}



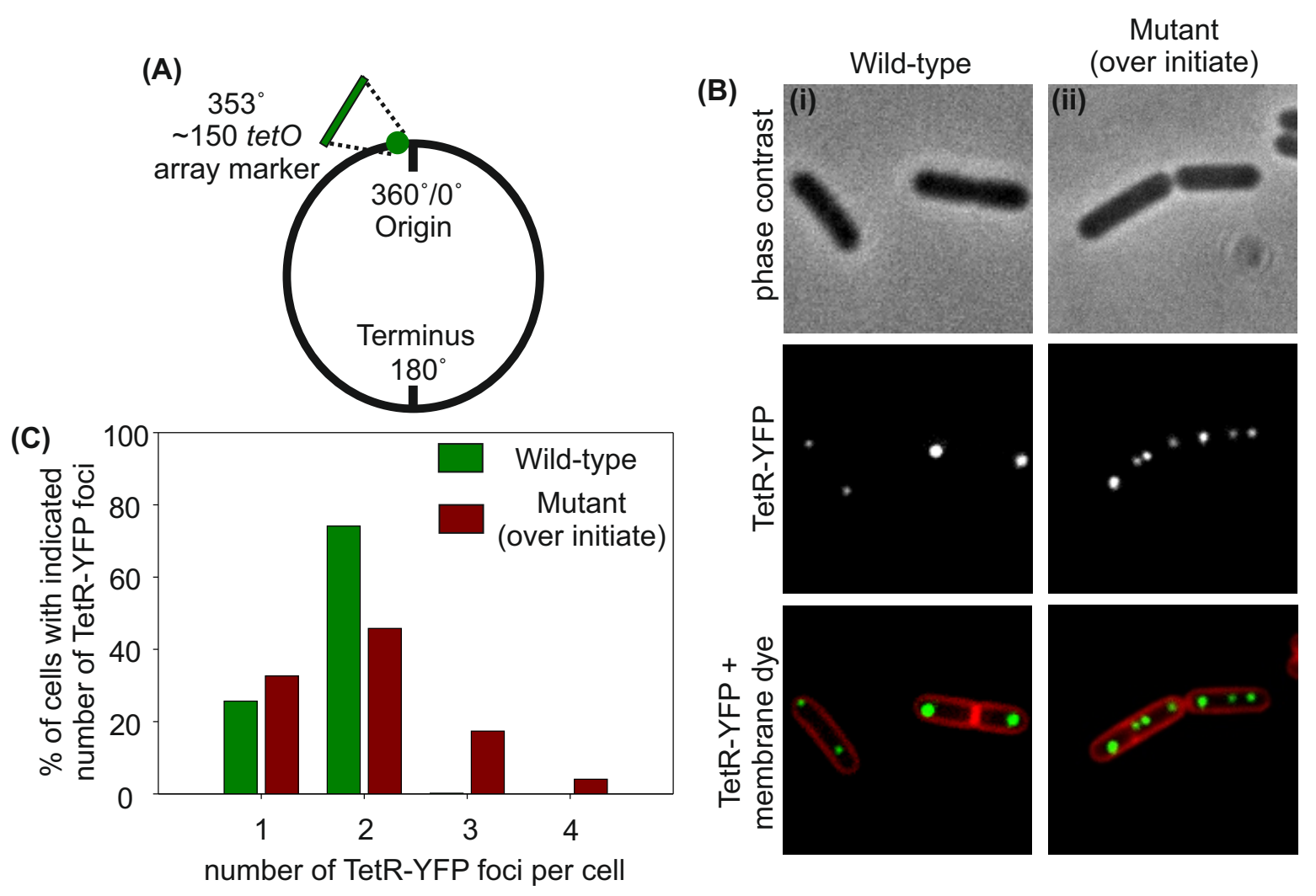

(D) (i) Origin position measurement

(ii) Terminus position

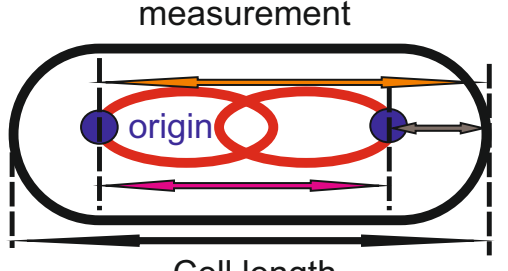

Cell length

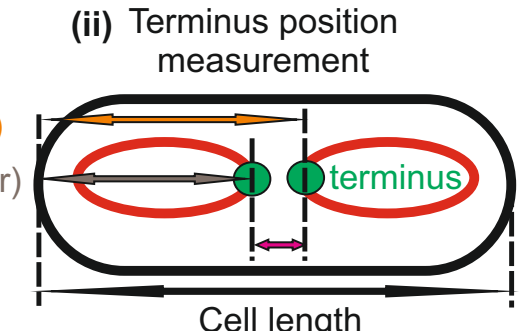

(E)

\begin{tabular}{|ccccc|}
\hline \multirow{2}{*}{ Strain } & Region & \multicolumn{2}{c|}{ \% of cell length $\pm \mathbf{9 5 \%} \mathbf{C l}$} \\
\cline { 3 - 4 } & $\begin{array}{c}\text { Interfocal } \\
\text { distance }\end{array}$ & $\begin{array}{c}\text { Average } \\
\text { position }\end{array}$ & $\begin{array}{c}\text { No. of cells } \\
\text { analysed }\end{array}$ \\
\hline TetR-GFP & Origin & $46.1 \pm 2.0$ & $27.0 \pm 1.2$ & 105 \\
Spo0J-GFP & Origin & $47.9 \pm 1.8$ & $26.1 \pm 1.3$ & 99 \\
RTP-GFP & Terminus & $18.5 \pm 1.5$ & $40.8 \pm 1.2$ & 100 \\
\hline
\end{tabular}


(i)

Random

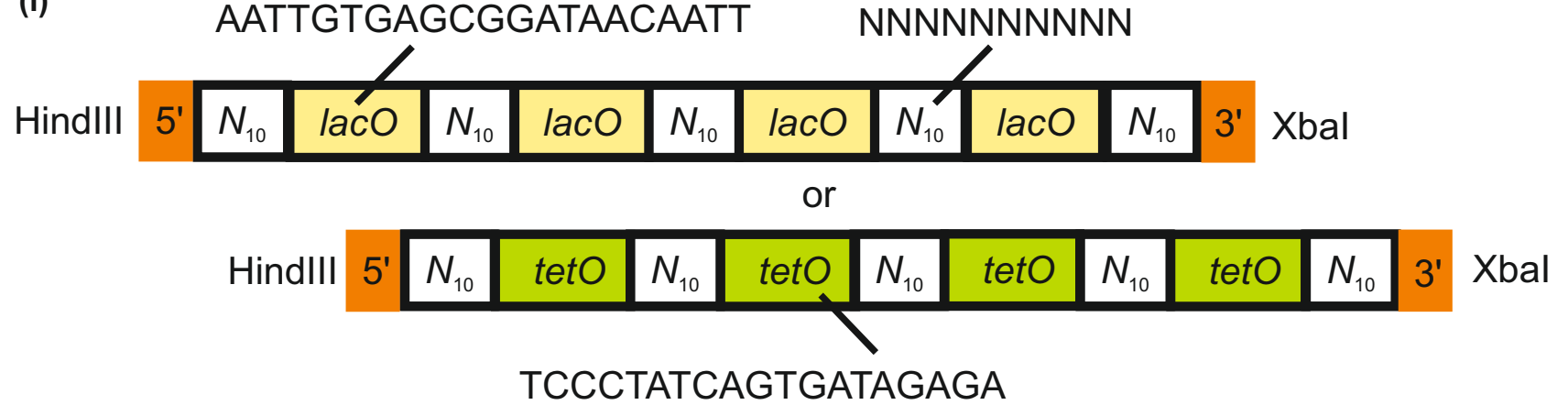

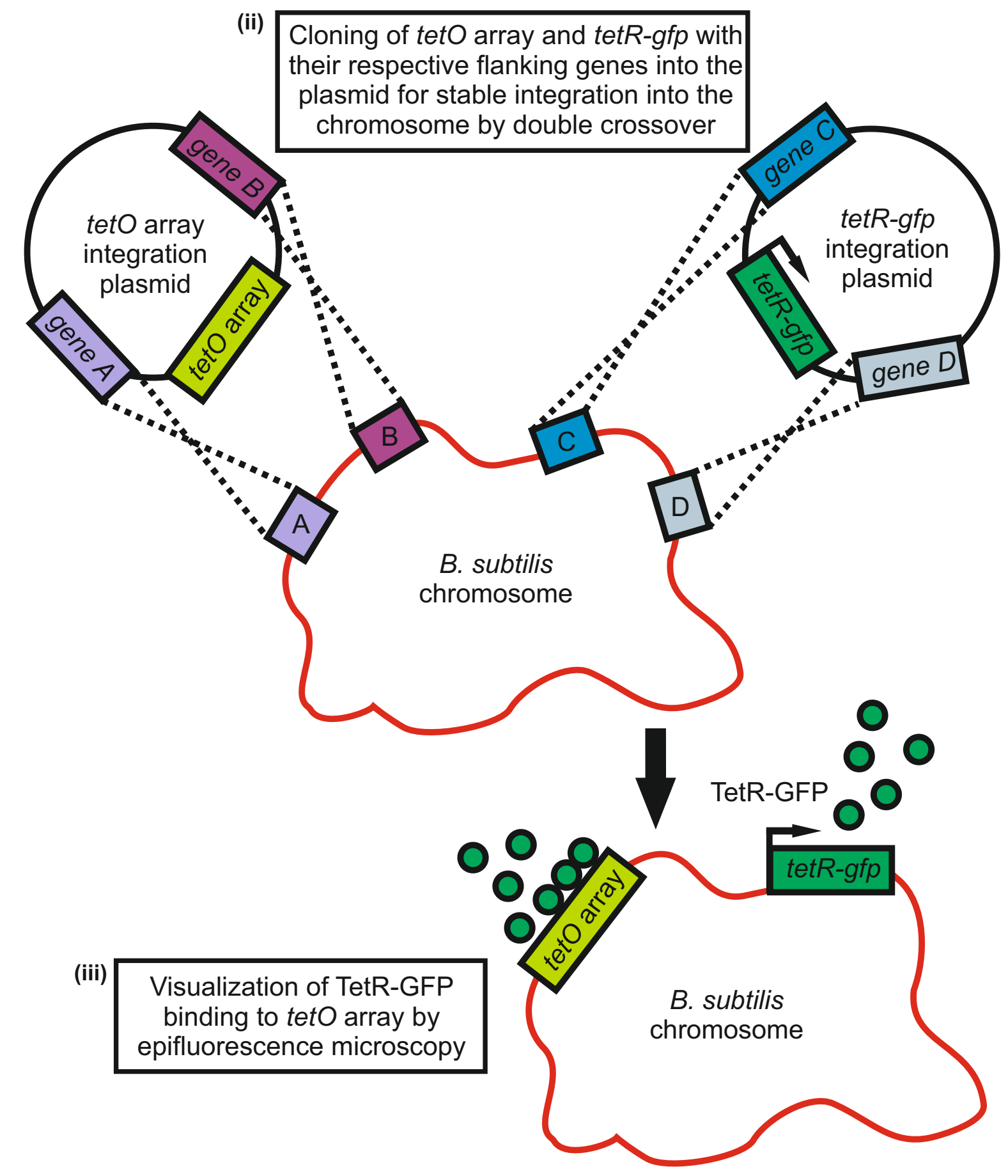



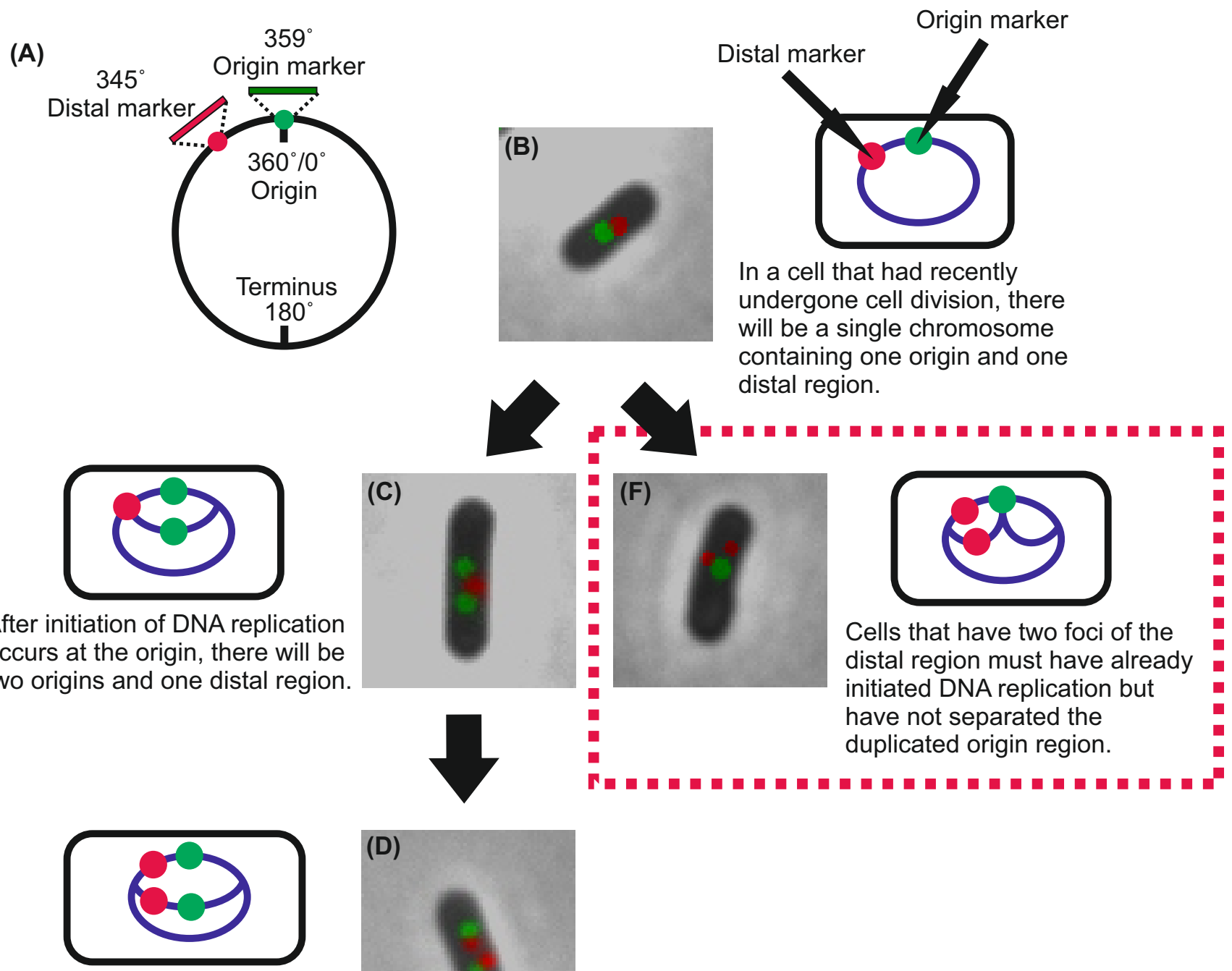

As replication proceeds along the chromosome arm, the distal region will be copied.
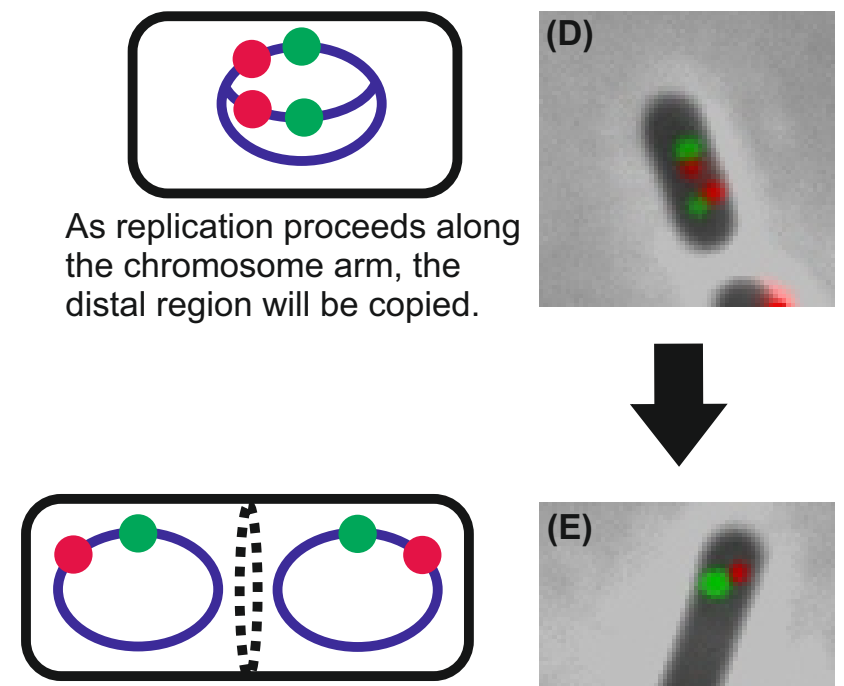

The cell division machinery will localize to mid-cell to drive cytokinesis, leading to the formation of two identical daughter cells. 
(B)

(A)

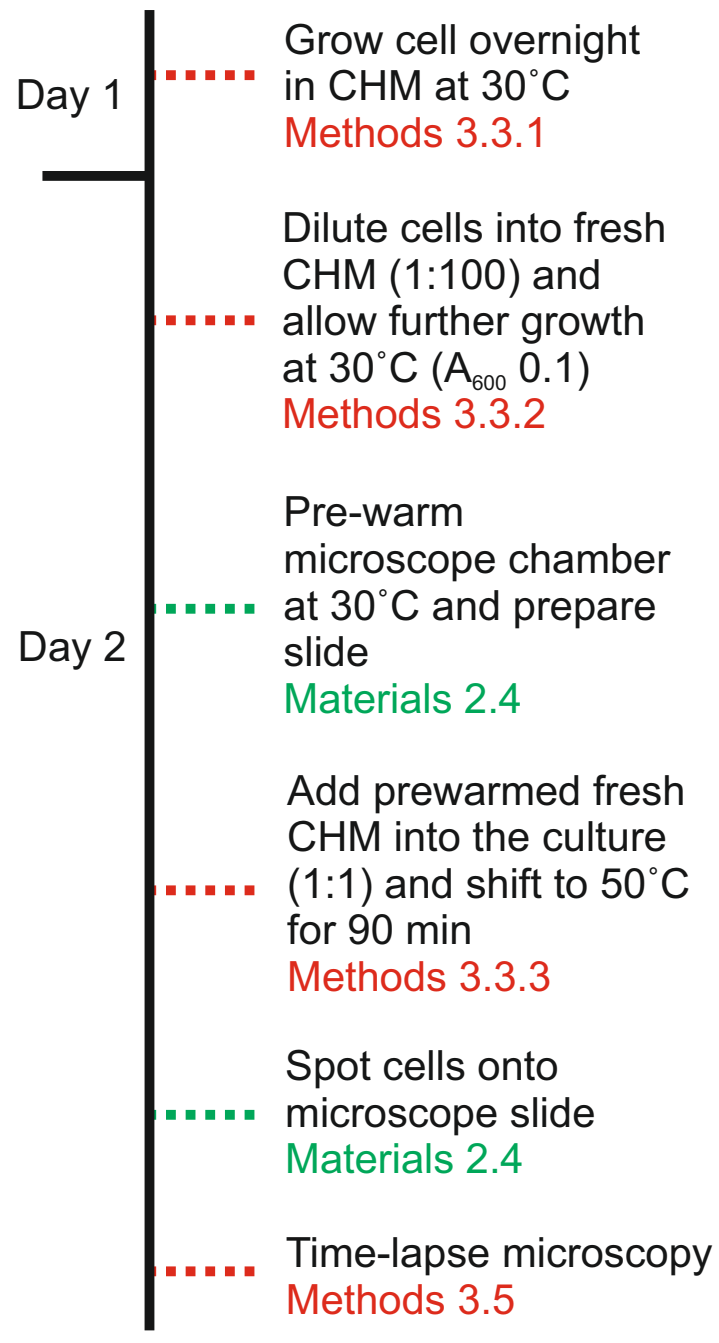

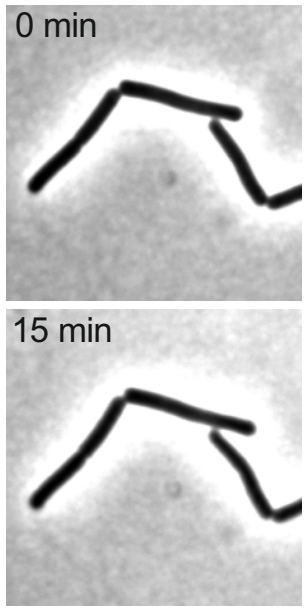
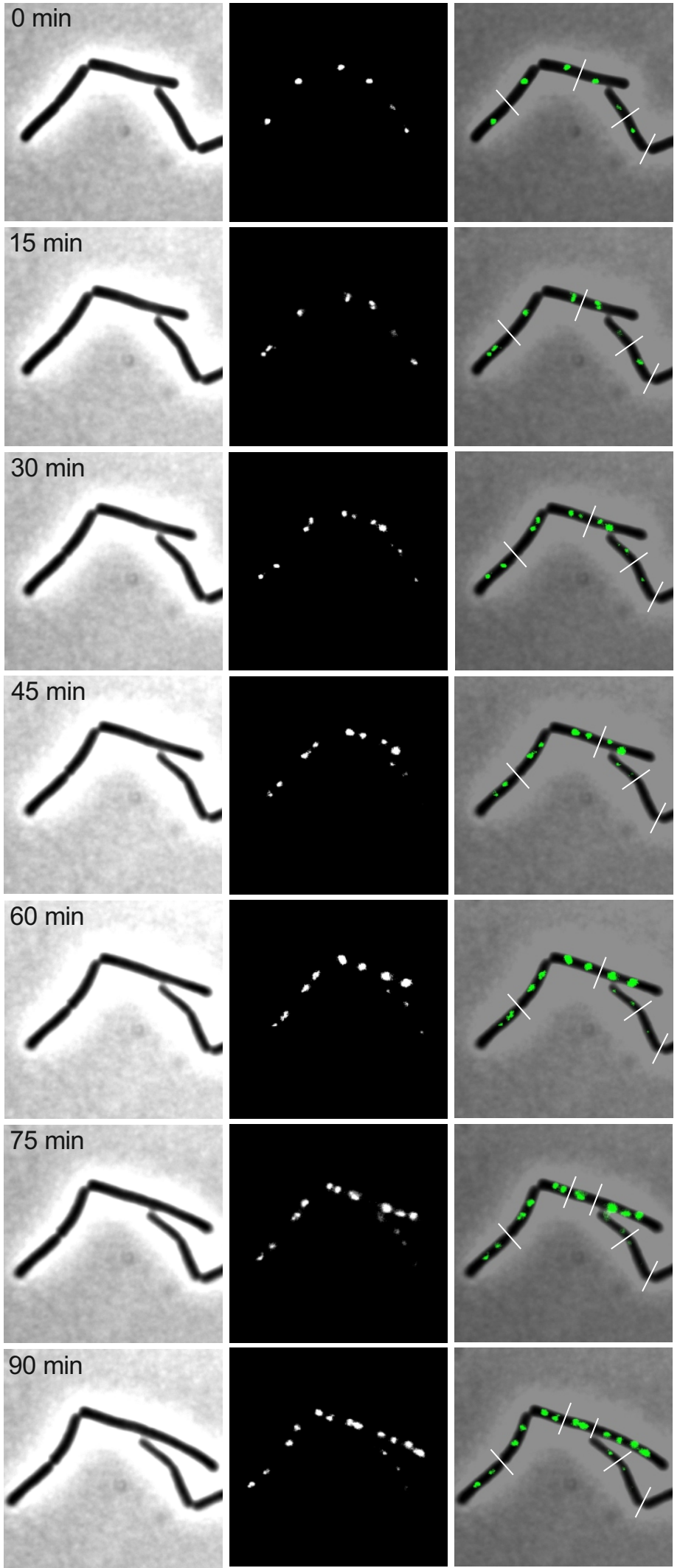

phase contrast
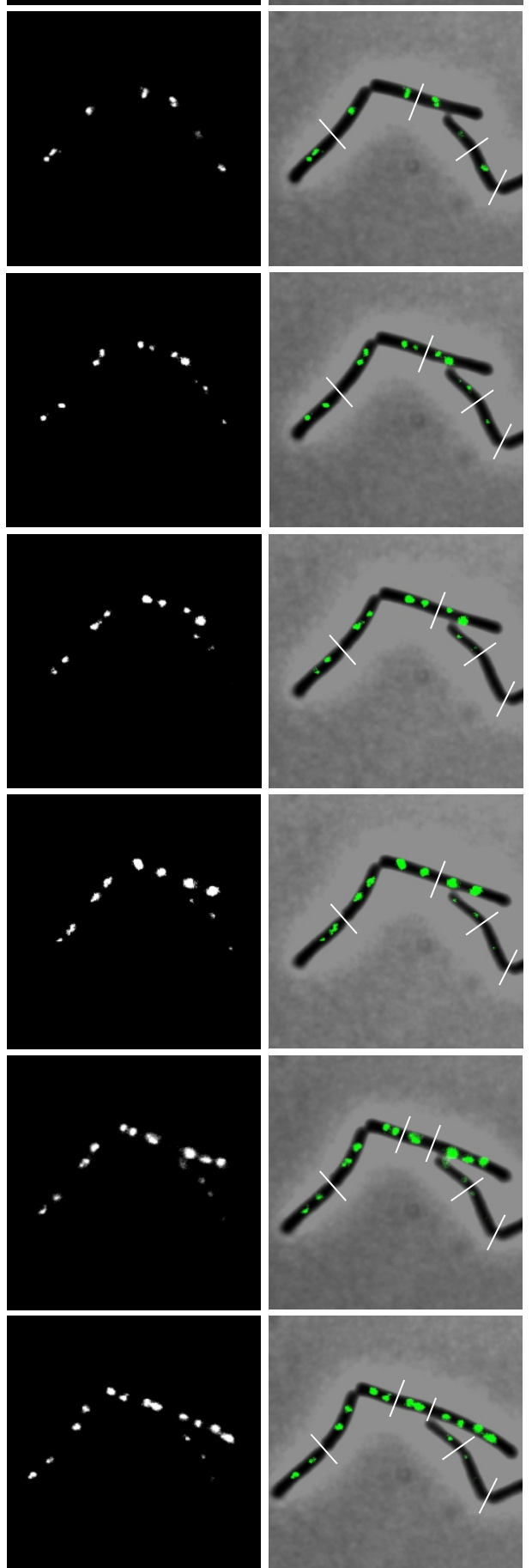

Spo0J-GFP

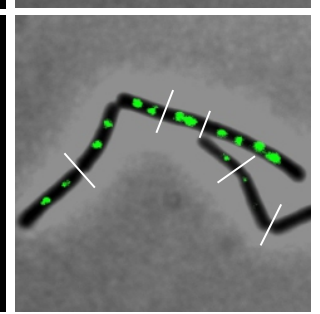

Spo0J-GFP + phase contrast 
(A)

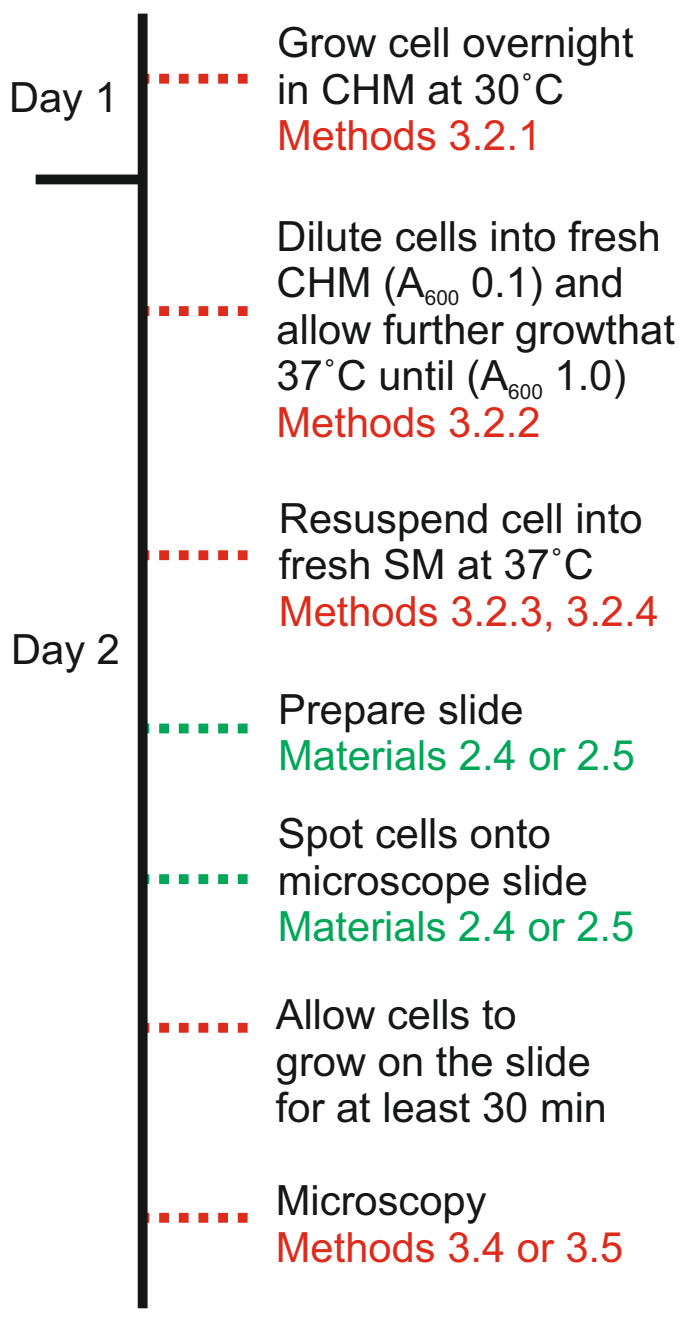

(C)

(i) top view (1 to 2 strains)

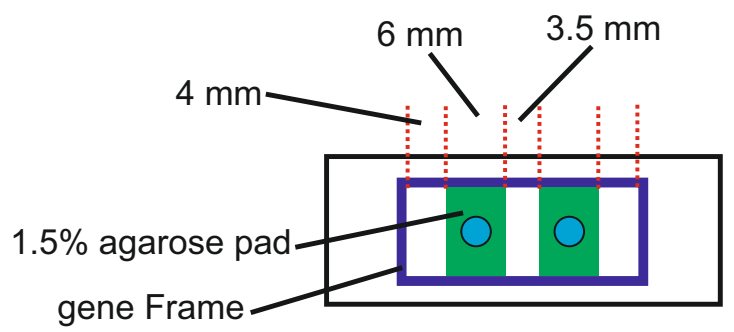

(ii) top view (1 to 4 strains)

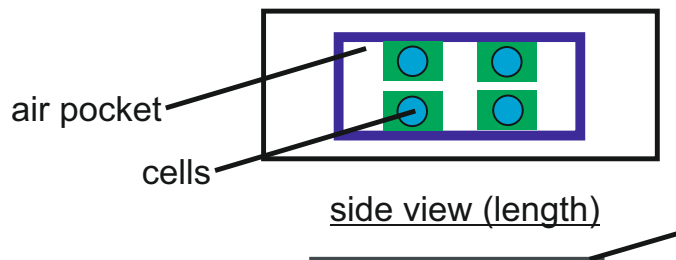

(B)
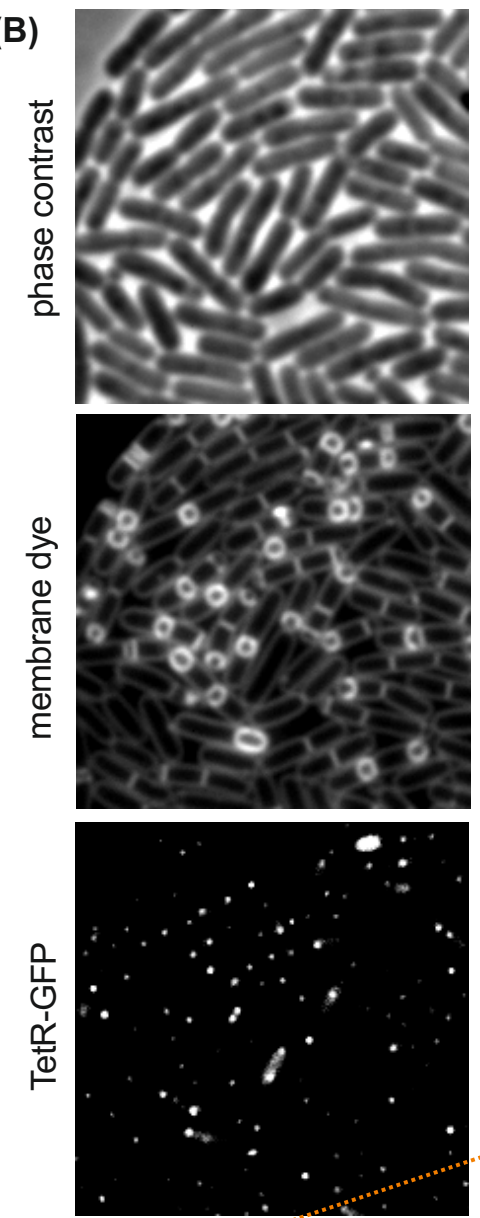

(i) normal cell

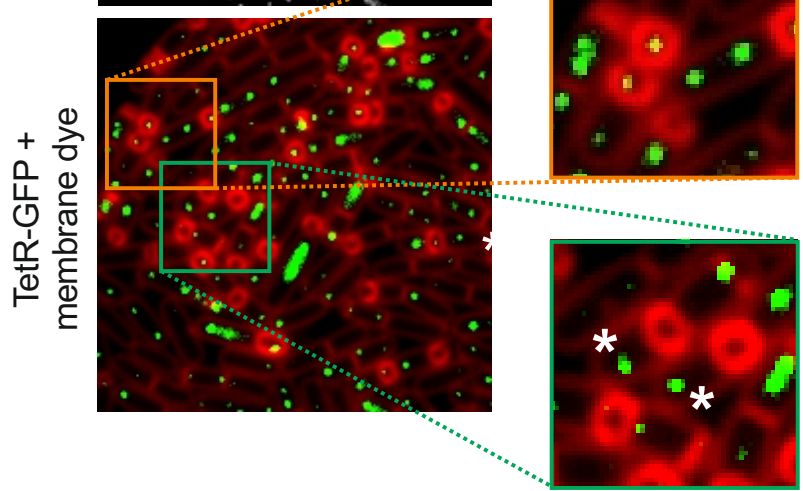

side view (width) cover slip defect

side view (width)

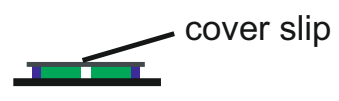
cover slip 